\title{
PERAN JURNALIS DALAM MEWARTAKAN BERITA PEMBELAJARAN JARAK JAUH DALAM MASA PANDEMI VIRUS CORONA DI INDONESIA
}

\author{
Khaerunnisa Agisti \\ Anis Fuadah Zuhri \\ UIN Syarif Hidayatullah Jakarta \\ JI. Ir. H. Djuanda No. 95, Cempaka Putih, Ciputat Timur, Tangerang Selatan \\ 15412, Banten, Indonesia \\ khairunnisaagisti04@gmail.com
}

Naskah masuk: 22-10-20, direvisi: 21-01-20, diterima: 11-02-20, dipublikasi: 30-04-20

\begin{abstract}
Abstrak: Jurnalis merupakan sebuah profesi dan setiap profesi pasti mempunyai etika, profesi jurnalis diatur oleh kode etik jurnalistik yang memuat aturan-aturan yang dibentuk dari norma dan nilai yang ada serta menurut undang-undang yang ada di Indonesia. Akhir tahun 2019, penduduk diseluruh Dunia mengetahui berita mengenai virus berbahaya yang disebut dengan virus corona atau Covid-19. Berita tersebut menimbulkan keresahan pada masyarakat, karena banyak sekali berita di televisi maupun media sosial menyampaikan berita mengenai virus corona tersebut. Dalam artikel ini akan membahas mengenai Peran Jurnalis dalam Mewartakan Berita Penyebaran Virus Corona di Indonesia. Dengan adanya artikel ini bertujuan untuk mengajak masyarakat untuk berpikir bagaimana cara mengolah berita yang terdapat di televisi maupun media sosial apakah fakta atau hoaks mengenai berita yang disampaikan dalam menghadapi, mencegah, dan bertahan hidup dalam situasi pada saat ini. Dalam artikel ini membahas: 1) Penyebaran Virus Covid-19 di Indonesia. 2) Peran Jurnalis Dalam Menyampaikan Berita Penyebaran Virus Covid-19 di Indonesia.
\end{abstract}

Kata kunci: Kode etik jurnalistik, Virus Covid-19, penyebaran Covid-19 di Indonesia

\begin{abstract}
Journalism is a profession and every profession must have ethics, the journalist profession is governed by a journalistic code of ethics that contains rules that are formed from existing norms and values and according to the laws in Indonesia. At the end of 2019, people around the world learned about the dangerous virus called the corona virus or Covid-19. The news caused unrest in the community, because a lot of news on television and social media delivered news about the corona virus. In this article, we will discuss the role of journalists in reporting news about the spread of Corona virus in Indonesia. The existence of this article aims to encourage the public to think about how to process the news contained on television and social media whether the facts or hoaxes about the news delivered in the face, prevent, and survive in the current situation. In this article discusses: 1) Spread of Covid-19 Virus in Indonesia. 2) The Role of Journalists in Delivering the News of the Covid-19 Virus Spread in Indonesia.
\end{abstract}

Keywords: Journalistic code of ethics, Virus Covid-19, the spread of Covid-19 in Indonesia

\section{PENDAHULUAN}

Adanya penerbitan media massa cetak ataupun media massa elektronik menjadi satu kendala untuk memenuhi kebutuhan masyarakat akan informasi. Media massa merupakan alat komunikasi yang dengan mudah digunakan untuk menyebarkan berita yang terjadi di berbagai dunia. Dari media massa mampu memberitahu kepada masyarakat di seluruh dunia untuk melihat berbagai peristiwa berupa informasi yang terjadi. Media massa meliputi media massa cetak dan media elektronik. Adapun media massa cetak seperti surat kabar, buku, 
tabloid dan majalah, lalu media massa elektronik seperti televisi, radio, internet, dll.

Kode etik adalah berbagai aturan atau etika yang harus dimiliki setiap wartawan atau jurnalis sesuai dengan tuntutan kewajiban dan amanah. Etika jurnalistik untuk melindungi seluruh masyarakat dari penyampaian berita yang berdampak negatif. Etika tersebut berhubungan dengan baik dan buruknya jurnalis dalam membawakan berita. Kode etik merupakan hal yang sangat penting, maka dari itu setiap jurnalis atau wartawan harus memahami setiap kode etik yang terdapat dalam Undang-Undang. Adapun Undang-Undang No. 40 Tahun 1999 tentang pers, menjadi awal dari tumbuhnya media massa di masyarakat. Selain Undang-Undang No. 40 tahun 1999 tentang pers, jurnalis juga datur oleh kode etik jurnalistik. (Arnus, 2014)

Pada prinsip Undang-Undang No. 40 Tahun 1999 dijelaskan bahwasannya setiap kegiatan kewartawanan merupakan kegiatan yang berhubungan dengan pengumpulan dan penyiaran informasi dalam bentuk fakta, pendapat atau ulasan, gambar-gambar dan sebagainya. Kode etik wartawan Indonesia pertama kali dikeluarkan oleh Persatuan Wartawan Indonesia (PWI) sebagai etika profesi kewartawanan, karena dibatasi oleh ketentuan hukum dalam UU Pers Nomor 40 Tahun 1999 wartawan harus berpegang kepada kode etik jurnalistik agar wartawan dapat bertanggung jawab dalam menjalankan profesinya untuk menyajikan dan mencari informasi. (Winarni \& Lestari, 2019)

Di Indonesia, pelanggaran kode etik dipengaruhi berbagai faktor. Pertama, sifatsifat kode etik yang berkaitan dengan sikap tiap individu jurnalis. Kedua, latar belakang jurnalis yang berbeda-beda. Banyak jurnalis yang belum disiapkan secara profesional karena berasal dari setiap kalangan yang berbeda-beda. Ketiga, makna yang terkandung dalam kebebasan pers tidak bisa dipahami oleh para pelaku media. Keempat, belum adanya tradisi professional untuk menghormati kode etik. Keloma, profesi jurnalis masih dianggap sebagai mata pencaharian. Keenam, perusahaan pers tidak memihak profesi jurnalis, terlihat dari para pemerintah memberikan upah masih kurang layak. (Lewi Pramesti, 2014)

Pada akhir tahun 2019, berita diseluruh dunia membahas mengenai penyakit menular yang dikenal dengan virus corona atau Covid-19. Virus ini termasuk penyakit menular yang baru ditemukan di Wuhan, China pada Desember 2019 yang kemudian menjadi wabah. World Health Organization (WHO) mengungkapkan bahwa virus corona berasal dari Coronaviruses (CoV) yang menyebabkan penyakit mulai dari flu biasa hingga yang lebih parah seperti Middle East Resoiratory Syndrome (MERS-CoV) dan Serve Acute Respiratory Syndrome (SARSCoV). Virus corona yang menyerang penduduk Wuhan pada saat ini telah masuk ke zona otoritas Indonesia. Coronavirus belum pernah diidentifikasi pada manusia.(Oktiani, 2020)

Coronavirus adalah zoonosis yaitu virus yang ditularkan antara hewan dan manusia. Virus ini menyerang sistem pernafasan yang mana membuat orang yang terjangkit memiliki gejala susah untuk bernafas, demam, batuk, dan bersin. Pada kasus yang lebih parah infeksi dapat menyebabkan pheunomia, sindrom pernapasan akut, gagal ginjal, bahkan kematian.

Kasus Covid-19 ini diduga berkaitan dengan pasar hewan Huanan yang ada di Wuhan, di pasar tersebut mereka menjual berbagai jenis daging binatang yang tidak biasa dikonsumsi, seperti ular kelelawar, dan berbagai jenis tikus. Kasus infeksi pheunomia banyak ditemukan di pasar hewan tersebut. Virus Covid-19 diduga 
berasal dari kelelawar dan hewan lain yang dimakan manusia hingga terjadi penularan. Kelelawar, ular, dan berbagai hewan eksotis lain kini masih dianggap sebagai faktor penyebaran virus Corona.

Coronavirus (nCoV) adalah virus jenis baru belum diidentifikasi sebelumnya pada manusia. Menurut WHO, Covid-19 menular melalui orang yang telah terinfeksi virus corona. Penyakit dapat menyebar melalui tetesan kecil dari hidung dan mulut ketika seseorang yang terinfeksi virus ini bersin atau batuk. Tetesan itu kemudian mendarat di sebuah benda atau permukaan yang disentuh oleh orang yang sehat kemudian ia menyentuh mata, hidung atau mulut mereka. Virus ini juga bisa menyebar ketika tetesan kecil tersebut dihirup seseorang ketika berdekatan dengan orang yang terinfeksi corona.

Gejala Covid-19 yang paling umum adalah demam, kelelahan, dan batuk kering. Beberapa pasien mungkin mengalami sakit dan nyeri, hidung tersumbat, pilek, sakit tenggorokan, atau diare. Gejala-gejala ini bersifat ringan dan terjadi secara bertahap. Beberapa orang yang terinfeksi tetapi tidak menunjukkan gejala apapun dan tak merasa tidak enak badan, kebanyakan mereka yang merasa seperti itu pulih dari penyakit tanpa perawatan khusus.

Sejumlah gejala Covid-19 memiliki kemiripan dengan gejala flu yang sering terjadi serta diikuti dengan demam, sakit kepala, dan batuk. Di tengah wabah virus seperti yang terjadi pada saat ini, sangat penting bagi kita untuk mengetahui perbedaan antara gejala virus corona dengan flu dan batuk biasa. Gejala batuk yang terjadi pada orang yang menderita influenza, menurut Centers for Disease Control and Prevention (CDC), batuk biasa sering kali terjadi secara tiba-tiba dan penderita akan sembuh dalam waktu relatif singkat, kurang dari 2 minggu. Selain itu, batuk yang terjadi pada orang yang menderita flu disertai dengan pilek dan bersin-bersin (Kompas.com, 2020b).

Menurut WHO, sebagian besar penderita yang terinfeksi virus corona mengalami batuk kering terus menerus, sesak napas atau pheunomia, tetapi tidak disertai sakit tenggorokan. Meski begitu, tidak semua batuk kering atau berdahak merupakan gejala virus corona karena batuk kering bisa menjadi tanda iritasi atau radang di tenggorokan. Penderita batuk kering tidak bisa disebut $100 \%$ penderita Covid-19, namun jenis batuk ini lebih berpotensi menjadi gejala Covid-19 daripada batuk basah yang menghasilkan dahak.

Virus Covid-19 merupakan virus yang sangat cepat penyebarannya di seluruh dunia. Kebijakan pemerintah di setiap negara menerapkan beberapa sistem dalam menghadapi kehidupan pada saat ini. Masyarakat dihimbau untuk menjalankan sistem yang telah ditetapkan, seperti isolasi, physical distancing, atau lockdown suatu wilayah. Peraturan ini ditetapkan agar seluruh masyarakat membatasi aktivitas di luar rumah dan menjauhi keramaian agar tidak semakin banyak orang yang terinfeksi virus ini.

\section{METODE}

Metode pustaka yang digunakan dalam artikel ini yakni menggunakan metode studi pustaka. Pendekatan kepustakaan atau studi pustaka ialah segala usaha yang dilakukan oleh penulis untuk menghimpun informasi yang relevan dengan topik atau masalah yang sedang diteliti. Informasi itu dapat diperoleh dari buku, jurnal, surat kabar dan majalah, ensiklopedia, dan berbagai sumber 
lainnya baik dari berita di televisi maupun media sosial.

Studi pustaka ini adalah metode penelitian di mana penulis tidak harus turun langsung ke lapangan untuk bertemu dengan sumber. Seorang penulis dapat menganalisis tulisannya dengan membandingkan karya-karya tulisan orang lain, sehingga memperoleh data yang spesifik. Berbagai sumber yang didapat oleh penulis dianggap sebagai sumber data yang akan dianalisis oleh penulis untuk karya ilmiah yang sedang diteliti dengan cara menelaah dan membandingkan sumber untuk memperoleh data yang akurat. Dengan menggunakan studi pustaka, penulis dapat memperoleh informasi metode penelitian yang diharapkan. Pada proses penulisan artikel ini, penulis mengumpulkan data-data yang berkaitan dengan tema pembahasan Peran jurnalis dalam mewartakan berita virus covid-19 di Indonesia.

Setelah memiliki sumber-sumber yang memadai dan terpercaya, penulis membaca secara mendalam, melakukan analisis dari sumber-sumber tersebut, dan mendiskusikan tentang hasil informasi yang diperoleh, serta meringkasnya supaya menjadi kesimpulan yang padat.

\section{HASIL DAN PEMBAHASAN}

Artikel ini bertujuan untuk mengajak masyarakat untuk berpikir bagaimana cara mengolah berita yang terdapat di televisi maupun media sosial apakah fakta atau hoaks mengenai berita yang disampaikan dalam menghadapi, mencegah, dan bertahan hidup dalam situasi pada saat ini. Pada saat menghadapi pandemi virus Covid-
19, banyak sekali berita yang tidak berasal dari situs resmi pemerintah pusat RI. Maka dari itu saya menghimbau masyarakat agar pandai dalam memilih berita yang terdapat di televisi, sosial media, dan sumber berita lainnya. Dalam menghadapi situasi saat ini, anjuran dari pemerintahlah yang sangat jelas untuk diikuti agar kita semua memutus penyebaran virus covid-19 dengan melakukan segala aktivitas baik itu bekerja maupun kegiatan belajar dari rumah saja secara online/daring.Berikut ini merupakan pembahasan hasil penelitian, diantaranya adalah sebagai berikut:

Wabah virus corona masih terus menyebar ke sejumlah negara di dunia termasuk negara Indonesia. Jika sebelumnya Indonesia menjadi salah satu negara yang belum terinfeksi, kini Tanah Air sudah mengonfirmasi kasus pertamanya. Gejala Covid-19 yang paling umum adalah demam, kelelahan, dan batuk kering. Beberapa pasien mungkin mengalami sakit dan nyeri, hidung tersumbat, pilek, sakit tenggorokan, atau diare. Gejala-gejala ini bersifat ringan dan terjadi secara bertahap. Beberapa orang yang terinfeksi tetapi tidak menunjukkan gejala apapun dan tak merasa tidak enak badan, kebanyakan mereka yang merasa seperti itu pulih dari penyakit tanpa perawatan khusus. Sekitar 1 setiap 6 orang mendapatkan Covid-19 sakit parah dan mengalami kesulitan bernafas. Sejumlah gejala Covid-19 memiliki kemiripan dengan gejala flu yang sering terjadi serta diikuti dengan demam, sakit kepala, dan batuk.

Awal mula penyebaran covid-19 di Indonesia pada tanggal 14 Februari 2020, pasien terinfeksi virus corona berdansa dengan WNA Jepang. Pasien berusia 31 tahun ini memang bekerja sebagai guru dansa dan WNA asal Jepang. Dua hari kemudian, pada tanggal 16 Februari 2020 pasien terkena sakit batuk. Pasien kemudian melakukan pemeriksaan di rumah sakit 
terdekat. Namun, pasien tersebut langsung dibolehkan untuk rawat jalan atau kembali ke rumah. Namun, beberapa hari kemudian sakit yang dideritanya tidak sembuh juga. Pada 26 Februari 2020, pasien dirujuk ke rumah sakit untuk menjalani rawat inap. Pada saat dirawat, batuk yang dideritanya disertai dengan merasakan sesak napas. Setelah menjalankan tahapan pemeriksaan di rumah sakit lama, maka hasil pemeriksaan tersebut menunjukkan bahwa pasien positif terinfeksi virus corona. Kemudian, pasien dipindahkan ke Rumah Sakit Penyakit Infeksi (RSPI) Sulianti Saroso, Jakarta Utara.

Pada hari Senin (2/3), Presiden Joko Widodo mengumumkan kasus pertama virus corona di Indonesia. Setelah penemuan kasus tersebut, pemerintah terus melakukan penelusuran dengan menelusuri aktivitas pasien. Hingga kemudian, ada dugaan virus corona itu tersebar di lokasi yang sama saat Kasus 1 melakukan kontak dekat dengan warga Jepang, di sebuah restoran di Jakarta. Penelusuran dilakukan dengan metode klaster, yaitu mencari orang-orang yang berada di lokasi yang sama, yaitu di restoran itu pada 14 Februari 2020. Pemerintah menelusuri pengunjung yang berada di restoran tersebut, terdapat tujuh pasien yang dilakukan pemeriksaan lanjutan. Dari hasil pemeriksaan lanjutan di RSPI Sulianti Saroso, pemerintah memastikan terdapat tiga pasien yang positif Covid-19 yaitu kasus 3, 4, dan 5 .

Adapun, pasien Kasus 6 merupakan salah satu awak kapal pesiar Diamond Princess, termasuk salah satu lokasi persebaran terbesar virus corona. Menurut Juru Bicara Pemerintah untuk Penanganan Virus Corona Achmad Yurianto, Kasus 6 merupakan "kasus import" yang didapat dari kapal pesiar Diamond Princess yang berlabuh di Jepang. Pasien kasus 6 ini kemudian dirawat di RSUP Persahabatan, Jakarta. Pada hari Minggu (8/3/2020) Kasus
Covid-19 di Indonesia bertambah dua orang. Juru Bicara pemerintah untuk penanganan virus corona Achmad Yurianto menyatakan bahwasannya pengidap Covid-19 menjadi enam orang.

Perkembangan kasus baru yang didapatkan terhitung tanggal 18 Maret pukul 12.00 WIB hingga 19 Maret pukul 12.00 WIB sebanyak 309 pasien positif Covid-19. Dibandingkan pada Rabu (18/3) kasus positif Covid-19 sebanyak 227 di 9 provinsi. Berikut adalah grafik pasien yang terjangkit virus Covid-19 pada 18 Maret 2020.

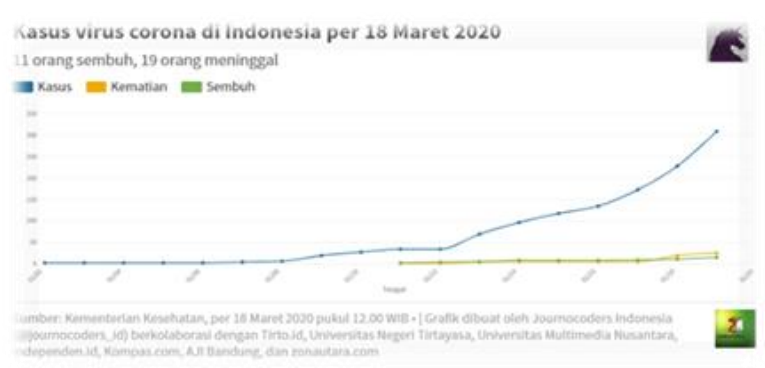

Gambar 1. Data Pasien Covid-19

Sumber: (Kementrian Kesehatan, per 18 Maret 2020)

Pada Kamis, 19 Maret 2020 pukul 12.00 WIB sesuai dengan pengumuman Kementerian Kesehatan Rl, terdapat penambahan 81 kasus positif baru terjangkit virus corona. Dengan demikian total pasien yang terjangkit ada sebanyak 308 orang. Adapun jumlah yang meninggal sebanyak 25 orang, dan 15 telah dinyatakan sembuh.

Sejak WHO mengumumkan bahwa virus corona yang tengah menyebar ke seluruh negara dinyatakan sebagai pandemi global, pemerintah Republik Indonesia mengeluarkan berbagai kebijakan agar masyarakat melakukan segala aktivitas dari rumah dan membatasi kegiatan di luar rumah yaitu dengan cara mengisolasi diri. Meskipun seseorang melakukan isolasi diri dirumah, maka dia masih boleh berada di tengah keluarganya tetapi harus menjaga jarak satu sama lain minimal dua meter. Kebijakan ini 
dibuat setelah banyak kasus warga negara Indonesia yang terjangkit virus covid-19. (Covid-19.go.id, 2020).

Kebijakan lain yang dihimbau pemerintah yaitu ketika hendak ke luar rumah maka diwajibkan untuk menggunakan masker mulut untuk melindungi masyarakat yang sehat agar tidak tertular virus Covid-19. Sebagaimana rekomendasi WHO agar seluruh masyarakat menggunakan masker saat beraktivitas di luar rumah. Masyarakat yang melakukan aktivitas di luar rumah dihimbau untuk selalu membawa handsinitizer, dan setelah sampai di rumah masyarakat diwajibkan untuk mencuci tangan dengan sabun agar terhindar dari virus tersebut.

Selama masa pandemi Covid-19, segala aktivitas masyarakat di Indonesia dilakukan melalui online dari rumah seperti belajar, bekerja, serta melakukan pembatasan sosial untuk memutus mata rantai penyebaran Covid-19. Semenjak pandemi covid-19, ekonomi negara Republik Indonesia mengalami dampak signifikan kepada seluruh masyarakat mulai dari pengusaha, pegawai, pekerja pabrik, bahkan yang paling mengalami dampak virus ini yaitu pelaku Usaha Mikro Kecil Menengah (UMKM). Oleh sebab itu, pemerintah memberikan prioritas utama untuk memenuhi kebutuhan pokok.

Presiden Joko Widodo dalam persnya di Istana Merdeka, Jakarta, pada Kamis, 9 April 2020 menyampaikan sejumlah bantuan sosial yang disiapkan pemerintah untuk menghadapi dampak virus Covid-19 bagi masyarakat kurang mampu. Presiden menjelaskan bahwa sebagian dana desa juga segera dialokasikan untuk bantuan sosial di desa. Bantuan tersebut diberikan kepada kurang lebih 10 juta keluarga penerima dengan besaran Rp 600 ribu per bulan selama 3 bulan dan total anggaran yang disiapkan adalah Rp21 triliun. Dalam menghadapi pandemi virus Covid-19, pemerintah akan terus berupaya untuk menyisir anggaran-anggaran yang tersedia untuk menambah lagi bantuan sosial dan memperluas peluang kerja bagi masyarakat di lapisan bawah untuk program padat karya. (Covid-19.go.id, 2020)

Perkembangan pasien yang terjangkit virus Covid-19 semakin bertambah. Achmad Yurianto mengumumkan adanya penambahan data terbaru sebanyak 192 pasien dinyatakan sembuh, kemudian kasus positif bertambah menjadi 2.491 dan 209 meninggal dunia di Indonesia per Senin (6/4). Dalam hal ini pasien yang sembuh bertambah 28 orang, kemudian positif menjadi 218 sementara yang meninggal bertambah 11 orang. Sebelumnya pada Minggu (5/4) tercatat kasus positif sebanyak 2.273 kasus, dengan rincian pasien sembuh sebanyak 164 orang, sementara 198 orang meninggal dunia. (CNN Indonesia, 2020).

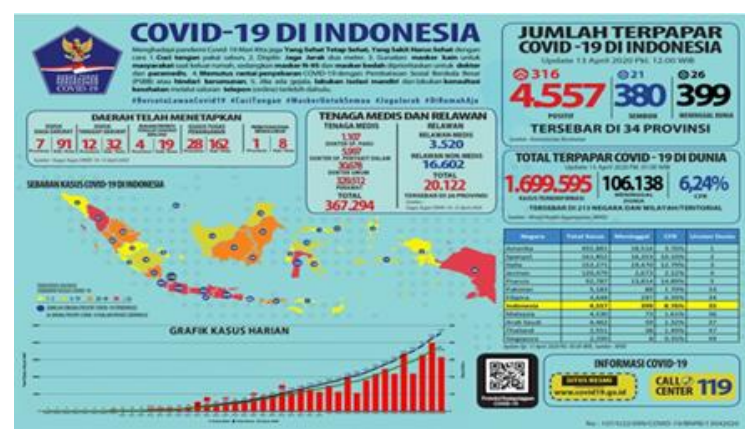

Gambar 2. Grafik Kasus Harian Pasien Covid-19 Sumber: (Covid-19, 2020)

Jumlah positif COVID-19 di Indonesia hingga Senin, 13 April, bertambah 316 kasus sehingga total positif 4.557 kasus, sementara yang sembuh 380 orang dan 399 meninggal dunia. Berdasarkan pencatatan sejak Minggu (12/4) pukul 12.00 WIB hingga Senin (13/4) pukul 12.00 WIB, pasien yang sembuh bertambah 21 orang, sementara yang meninggal bertambah 26 orang. Sebelumnya pada Minggu (12/4) tercatat 
kasus positif COVID-19 sebanyak 4.241 kasus, dengan pasien sembuh sebanyak 359 orang, dan meninggal dunia 373 orang. Sebagian besar yang meninggal ini terutama pada kelompok usia di atas 50 tahun dan memiliki penyakit-penyakit sebelumnya seperti tekanan darah tinggi, diabetes, dan penyakit paru-paru yang kronis.(Covid19.go.id, 2020)

Pandemi virus Covid-19 yang kini telah menyebar di Negara Indonesia bukan hanya berdampak dalam segi perekonomian saja, akan tetapi dalam bidang pendidikan juga. Kementerian Pendidikan dan Kebudayaan (Kemendikbud) menerbitkan dua surat edaran terkait pencegahan dan penanganan virus tersebut. Adapun yang pertama, Surat Edaran Nomor 2 Tahun 2020 tentang Pencegahan dan Penanganan COVID-19 di lingkungan Kemendikbud dan Surat Edaran Nomor 3 Tahun 2020 tentang Pencegahan COVID-19 pada Satuan Pendidikan. Menteri Pendidikan dan Kebudayaan (Mendikbud) Nadiem Anwar Makarim menyampaikan bahwa Surat Edaran Nomor 3 Tahun 2020 tentang Pencegahan COVID-19 ini adalah panduan dalam menghadapi penyakit tersebut di tingkat satuan pendidikan. (Kemdikbud, 2020b)

Saat ini, sekolah dan beberapa kampus di Indonesia telah membuat kebijakan untuk melakukan pembelajaran jarak jauh. Kemendikbud mendorong penyedia teknologi dan konten pendidikan untuk bergotong-royong mendukung pembelajaran daring selama masa pandemi. Dalam memudahkan kegiatan pembelajaran saat ini, kemendikbud membantu guru untuk melaksanakan kegiatan pembelajaran jarak jauh/daring dengan meluncurkan berbagai program yang bisa diakses dengan mudah oleh siswa untuk meningkatkan semangat belajar dan meningkatkan strategi pembelajaran agar lebih kreatif dan efektif.
Kemendikbud meluncurkan berbagai program untuk pembelajaran daring seperti portal rumah belajar yang dapat diakses di belajar.kemdikbud.go.id.

Selain itu terdapat program guru berbagi dapat diakses melalui laman guruberbagi.kemdikbud.go.id, program ini membantu guru dalam melaksanakan pembelajaran daring pada saat pandemi Covid-19. (kemdikbud, 2020)

Presiden Joko Widodo menjelaskan bahwa dalam situasi pandemi virus korona atau Covid-19 saat ini semua pengambilan keputusan harus berhati-hati dan tidak terburu-buru. Hal tersebut berlaku untuk menetapkan kebijakan Pembatasan Sosial Berskala Besar (PSBB) yang diajukan oleh pemerintah daerah. Menurut presiden Jokowi, pelaksanaan PSBB tidak diberlakukan secara serentak dan seragam di seluruh Indonesia. Pemerintah harus melihat kondisi masing-masing daerah terlebih dahulu sebelum nantinya Menteri Kesehatan menetapkan status PSBB di daerah tersebut sesuai dengan peraturan dan undang-undang yang berlaku. Seperti yang telah kita ketahui, dalam Peraturan Pemerintah Nomor 21 Tahun 2020 dijelaskan bahwa PSBB meliputi peliburan sekolah dan tempat kerja, pembatasan kegiatan keagamaan, dan pembatasan kegiatan di tempat fasilitas umum. Presiden menjelaskan bahwa keputusan menetapkan status PSBB di suatu daerah didasarkan pada pertimbangan berbagai hal. (presidenri.go.id, 2020)

$$
\text { DKI Jakarta menerapkan }
$$

Pembatasan Sosial Berskala Besar atau dikenal dengan sebutan PSBB mulai berlaku pada tanggal 10/4/2020. Berdasarkan keputusan gubernur DKI Jakarta Nomor 380 Tahun 2020 tentang Pemberlakuan Pembatasan Sosial Berskala Besar Dalam Penanganan Corona Virus Disease 2019 (Covid-19). Selama masa PSBB, aktivitas- 
aktivitas di luar rumah akan dibatasi, sekolah ditutup, dan tempat ibadah ditutup untuk umum. Beberapa fasilitas umum juga dihimbau untuk melakukan penutupan tempat. Namun untuk supermarket, minimarket, pasar, toko atau tempat penjualan obat-obatan dan peralatan medis, kebutuhan pangan, barang kebutuhan pokok, dan fasilitas pelayanan kesehatan, atau fasilitas umum untuk pemenuhan kebutuhan dasar penduduk lainnya tetap masih dibuka.

Berdasarkan Pergub DKI Jakarta Nomor 33 Tahun 2020 Pasal 21 disebutkan bahwa penduduk rentan mendapatkan bantuan sosial dari Pemerintah Provinsi DKI Jakarta. Adapun bantuan sosialnya berupa bahan pokok sehari-hari. Selama PSBB, semua warga DKI memiliki hak yang sama dalam beberapa hal, diantaranya yaitu pelayanan dasar sesuai kebutuhan medis. Selama masa PSBB, pemberian bantuan untuk masyarakat miskin dan rentan miskin merupakan tanggung jawab pemerintah (kompas.com, 2020). Adapun arahan yang diberikan Gubernur DKI Jakarta Anies Baswedan dalam menghadapi PSBB di Jakarta yaitu sebagai berikut.

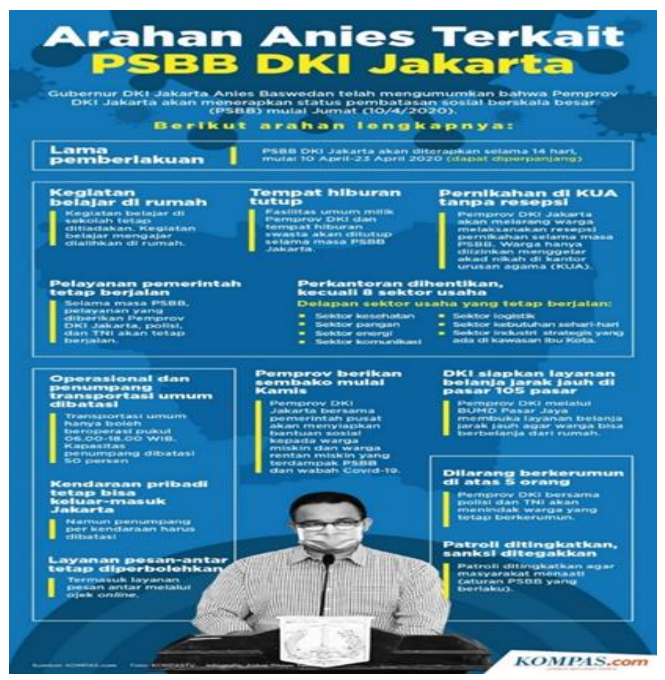

Gambar 3. Arahan Gubernur DKI Jakarta Mengenai PSBB

Sumber: (Kompas.com, 2020)
Setelah DKI Jakarta menerapkan PSBB, Lima wilayah di Jawa Barat, yakni Kota Bogor, Kabupaten Bogor, Kota Depok, Kota Bekasi, dan Kabupaten Bekasi, memutuskan pelaksanaan pembatasan sosial berskala besar (PSBB) serentak yang berlaku mulai Rabu (15/4/2020). Kepastian itu disampaikan langsung oleh Gubernur Jawa Barat Ridwan Kamil usai menggelar video conference di depan lima kepala daerah Bodebek, Minggu (12/4/2020). Diberlakukannya PSBB di lima wilayah tersebut, menyerahkan kebijakan kepada masing-masing kepala daerah agar menyiapkan aturan kebijakannya. Termasuk Wali Kota Bekasi mengatur PSBB dikotanya.(Kompas.com, 2020a)

Adapun beberapa daerah yang telah menerapkan PSBB untuk mencegah penyebaran virus Corona sampai dengan tanggal 8 Mei yaitu sebagai berikut.

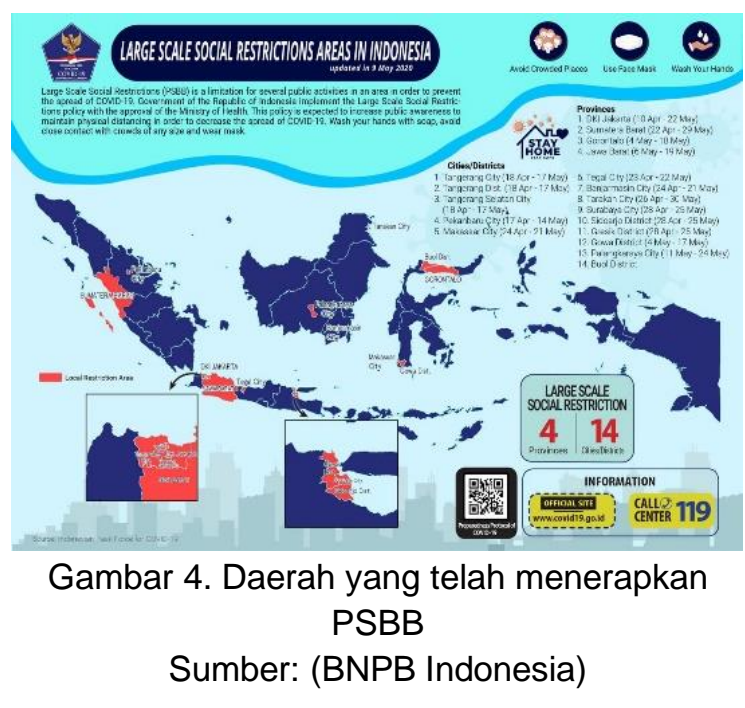

Penyebaran virus Covid-19 sangatlah cepat, pemerintah $\mathrm{Rl}$ sangat menghimbau masyarakat untuk mengikuti setiap kebijakan-kebijakan yang telah ditetapkan secara resmi pada saat ini. Dengan mentaati PSBB yang telah dikeluarkan oleh pemerintah merupakan salah satu cara kita semua sebagai warga 
negara untuk memutuskan penyebaran virus ini. Setelah presiden Joko Widodo menetapkan kebijakan Pembatasan Sosial Berskala Besar (PSBB) diberbagai daerah terbanyak pasien yang terjangkit, pada saat ini telah mengalami penurunan penderita yang terjangkit virus Covid- 19 .

Pada 15 Juni 2020, Kemendikbud bersama dengan Gugus Tugas Percepatan Penanganan Covid-19 dan bersama kementerian lainnya mengumumkan rencana penyusunan keputusan tentang panduan Penyelenggaraan Pembelajaran Tahun Ajaran dan Tahun Akademik Baru di Masa Pandemi Covid-19 saat ini. Panduan yang telah disusun bertujuan untuk mempersiapkan pendidikan saat menjalani masa kebiasaan baru dengan memperioritaskan kesehatan dan keselamatan peserta didik, pendidik, dan tenanga kependidikan lainnya, keluarga, dan masyarakat sekitar.

Menurut kebijakan yang telah disepakati oleh kementerian, Nadiem Makarim menjelaskan bahwasannya tahun ajaran baru 2020/2021 tetap dimulai pada bulan Juli 2020, akan tetapi untuk daerah yang berada di zona kuning, orange, dan merah tidak boleh melakukan pembelajaran tatap muka di satuan pendidikan. Maka dari itu, daerah yang terdapat di zona-zona tersebut tetap menjalankan belajar dari rumah secara daring.

Untuk kabupaten/kota dalam zona hijau, bagi satuan pendidikan yang akan mengambil keputusan untuk dimulainya pembelajaran tatap muka dan pemerintah kabupaten/kota telah memberi izin maka harus mengikuti persyaratan yang ketat dan wajib dipenuhi setiap satuan pendidikan yang akan melakukan pembelajaran tatap muka dengan menerapkan protokol kesehatan. Pembelajaran tatap muka dapat dilakukan secara bertahap pada masa kebiasaan baru dengan mengikuti ketentuan-ketentuan yang telah disepakati. (Kemdikbud, 2020a)

\section{Peran Jurnalis Dalam Menyampaikan Berita (Kode Etiktik Jurnalis) Pencegahan, Penyebaran Virus Covid-19 di Indonesia}

Dalam menyampaikan berita, peran para jurnalis Indonesia harus mengikut kode etik yang telah diatur dalam Undang-Undang yang telah ditetapkan Maka dari itu, jurnalis harus memahami ketentuan-ketentuan etik dan ketentuan hukum dalam UndangUndang. Kode etik jurnalistik dibuat untuk menjaga standar kualitas dari para jurnalis atau wartawan dalam menjalankan pekerjaannya agar profesional dan bertanggung jawab. Etika jurnalistik bertujuan untuk melindungi seluruh masyarakat dari penyampaian berita yang berdampak negatif. Para media dalam yang menyampaikan berita pencegahan virus covid-19, diwajibkan untuk memastikan bahwa pemerintah sudah menangani para penderita virus corona secara maksimal dan melakukan segala kebijakan-kebijakan yang harus dilakukan demi mencegah penyebaran virus ini. Para media harus menghindari berita yang membuat masyarakat panik, karena dari rasa panik tersebut sangat menggganggu kejiwaan seseorang dalam menghadapi pandemi saat ini. Para jurnalis memiliki beberapa tantangan dalam menyampaikan berita penyebaran virus Covid di Indonesia, selama masa pandemi banyak sekali berita yang muncul baik di televisi maupun sosial media yang membuat bingung dan meresahkan masyarakat. Dengan banyaknya informasi yang tersebar, sangat sulit untuk masyarakat percaya karena perbedaan pendapat mengenai berita tersebut. Sebagai warga negara kita harus pandai dalam memilih setiap berita apakah berita tersebut benar dan tidak mengandung unsur hoaks/penipuan, maka 
kita perlu memeriksa terlebih dahulu berita tersebut. Jika sumber berita tersebut diambil dari situs resmi milik negara maka besar kemungkinan bahwa berita tersebut jelas sesuai dengan fakta. Saat ini, peran jurnalis selalu mengikuti perkembangan wabah dan memberikan informasi yang akurat dari pemerintah $\mathrm{Rl}$ dengan sebaik-baiknya. Seperti informasi jumlah kasus disetiap harinya, respon negara dalam menghadapi pandemi saat ini, bagaimana cara pencegahan yang dapat dilakukan setiap individu, dan kebijakan-kebijakan baru yang telah ditetapkan di berbagai daerah Indonesia. Dalam menghadapi pandemi saat ini, peran jurnalis Indonesia sudah mengikuti kode etik jurnalistik yang telah ditetapkan dalam Undang-Undang.

\section{PENUTUP}

Coronavirus adalah virus yang ditularkan antara hewan dan manusia. Virus ini menyerang sistem pernafasan yang mana membuat orang yang terjangkit memiliki gejala susah untuk bernafas, demam, batuk, dan bersin. Pada kasus yang lebih parah infeksi dapat menyebabkan pheunomia, sindrom pernapasan akut, gagal ginjal, bahkan kematian. Menurut WHO, sebagian besar penderita yang terinfeksi virus corona mengalami batuk kering terus menerus, sesak napas atau pheunomia, tetapi tidak disertai sakit tenggorokan.

Meski begitu, tidak semua batuk kering atau berdahak merupakan gejala virus corona karena batuk kering bisa menjadi tanda iritasi atau radang di tenggorokan. Penderita batuk kering tidak bisa disebut penderita Covid-19, namun jenis batuk ini lebih berpotensi menjadi gejala Covid-19 daripada batuk basah yang menghasilkan dahak. Indonesia merupakan salah satu negara yang terjangkit virus Covid-19, setelah presiden Joko Widodo mengumumkan pasien pertama yang terjangkit virus ini, pemerintah RI menetapkan berbagai kebijakan-kebijakan baru untuk menghadapi pandemi saat ini.

Adapun kebijakan-kebijakan tersebut yaitu melakukan segala aktivitas dari rumah seperti bekerja, belajar secara online/ daring, ibadah dari rumah, silaturahmi dengan kerabat dapat dilakukan melalui media sosial, keluar rumah hanya untuk keperluan yang sangat penting seperti membeli keperluan kehidupan sehari-hari dan ketika keluar rumah diwajibkan untuk memakai masker lalu jangan lupa untuk mencuci tangan menggunakan sabun dengan benar ketika sampai di rumah, menjauhkan keramaian, masyarakat tidak boleh mudik/pulang kampung dikhawatirkan terkena virus, dan mengikuti peraturan PSBB. Sebagaimana kebijakan-kebijakan yang telah ditetapkan oleh pemerintah, kita sebagai warga negara yang baik wajib untuk mematuhi segala kebijakan tersebut demi membantu tenaga medis dan pemerintah RI dalam memutus penyebaran virus Covid-19. Pada masa pandemi saat ini banyak sekali berita yang tersebar baik di televisi maupun media sosial.

Maka dari itu, kita sebagai warga negara harus pandai dalam memilih setiap berita apakah berita tersebut benar dan tidak mengandung unsur hoaks/penipuan, kemudian kita perlu memeriksa terlebih dahulu berita tersebut. Jika sumber berita tersebut diambil dari situs resmi milik negara maka besar kemungkinan bahwa berita tersebut jelas sesuai dengan fakta. Dalam menyampaikan berita pencegahan virus covid-19, para media diwajibkan untuk memastikan bahwa pemerintah sudah menangani para penderita virus corona secara maksimal dan melakukan segala kebijakan-kebijakan yang harus dilakukan demi mencegah penyebaran virus ini dan media harus menghindari berita yang membuat masyarakat panik. Dalam 
menghadapi pandemi saat ini, peran jurnalis Indonesia sudah mengikuti kode etik jurnalistik yang telah ditetapkan dalam Undang-Undang.

\section{UCAPAN TERIMA KASIH}

Syukur Alhamdulillah kami panjatkan kepada Allah SWT karena berkah, rahmat, dan hidayah-Nya sehingga penulis dapat menyelesaikan artikel ini. Terimakasih kami ucapkan kepada dosen pembimbing yang selalu memberikan arahan dan motivasi sehingga artikel ini dapat terselesaikan dengan baik.

\section{REFERENSI}

Arnus, S. H. (2014). Industrialisasi media massa dan etika jurnalistik. Al-Munzir, 7(2), 101-114.

CNN Indonesia. (2020). Update Corona 6 April: 2.491 Kasus, 209 Meninggal, 192 Sembuh.

www.cnnindonesia.comdonesia.com/. https://www.cnnindonesia.com/nasional/ 20200406141046-20-490780/updatecorona-6-april-2491-kasus-209meninggal-192-sembuh

Covid-19.go.id. (2020a). Bertambah 316 Kasus, Positif COVID-19 di Indonesia Menjadi $4.557 \quad$ Kasus. www.covid19.go.id.

https://www.covid19.go.id/2020/04/13/be rtambah-316-kasus-positif-covid-19-diindonesia-menjadi-4-557-kasus/

Covid-19.go.id. (2020b). Kemenkes: Isolasi Diri Menjaga Jarak Fisik. www.who.int.emergencies. https://www.covid19.go.id/2020/04/06/ke menkes-isolasi-diri-menjaga-jarak-fisik/

Covid-19.go.id. (2020c). Upaya-Upaya Pemerintah Penuhi Kebutuhan Pokok Masyarakat di Tengah Pandemi Covid19. www.covid19.go.id. https://www.presidenri.go.id/siaranpers/upaya-upaya-pemerintah-penuhikebutuhan-pokok-masyarakat-di-tengahpandemi-covid-19/

kemdikbud. (2020). Bantu Guru Selenggarakan Pembelajaran Jarak
Jauh, Kemendikbud Luncurkan Guru Berbagi. kemdikbud.go.id. https://www.kemdikbud.go.id/main/blo g/2020/03/bantu-guru-selenggarakanpembelajaran-jarak-jauh-

kemendikbud-luncurkan-guru-berbagi

Kemdikbud. (2020a). Panduan Penyelenggaraan Pembelajaran pada Tahun Ajaran dan Tahun Akademik Baru di Masa Covid-19. kemdikbud.go.id.

https://www.kemdikbud.go.id/main/blo g/2020/06/panduan-

penyelenggaraan-pembelajaran-

pada-tahun-ajaran-dan-tahun-

akademik-baru-di-masa-covid19

Kemdikbud. (2020b). Sikapi COVID-19, Kemendikbud Terbitkan Dua Surat Edaran. kemdikbud.go.id. https://www.kemdikbud.go.id/main/blo g/2020/03/sikapi-covid19-

kemendikbud-terbitkan-dua-suratedaran

kompas.com. (2020). PSBB Jakarta Mulai Berlaku, Apa Saja Bantuan yang Didapatkan Warga? www.kompas.com.

https://www.kompas.com/tren/read/20 20/04/10/090200265/psbb-jakartamulai-berlaku-apa-saja-bantuanyang-didapatkan-warga?page=all\#page 3

Kompas.com. (2020a). Bogor, Depok, dan 
Bekasi Sepakat Lakukan PSBB Serentak Mulai Rabu. www.megapolitan.kompas.com. https://megapolitan.kompas.com/read /2020/04/13/10325741/bogor-depokdan-bekasi-sepakat-lakukan-psbbserentak-mulai-rabu?page=all\#page3

Kompas.com. (2020b). Pahami, Ini Perbedaan Batuk karena Gejala Terinfeksi Virus Corona dan Batuk Biasa.

https://www.kompas.com/tren/read/20 20/03/24/080256865/pahami-iniperbedaan-batuk-karena-gejalaterinfeksi-virus-corona-dan-batuk

Lewi Pramesti, O. (2014). Penerapan Kode Etik di Kalangan Jurnalis. Jurnal ILMU KOMUNIKASI, 11(1), 81-92. https://doi.org/10.24002/jik.v11i1.386

Oktiani, V. (2020). Apa yang Dimaksud Virus Corona? Ini Asal Mula hingga Gejala Covid-19. www.wolipop.detik.com.

https://wolipop.detik.com/health-anddiet/d-4946027/apa-yang-dimaksudvirus-corona-ini-asal-mula-hinggagejala-covid-19

presidenri.go.id. (2020). Presiden: Pengambilan Keputusan Terkait PSBB Harus Hati-hati. www.presidenri.go.id.

https://www.presidenri.go.id/siaranpers/presiden-pengambilankeputusan-terkait-psbb-harus-hatihati/
Winarni, N., \& Lestari, R. D. (2019). Netizen News Sources in the Journalistic Ethics Perspective (Case Study in Online Media Jogja.tribunnews.com). Journal Pekommas, 4(1), 85. https://doi.org/10.30818/jpkm.2019.20 40109. 